\title{
Tourism Development Strategies, SWOT analysis and improvement of Albania's image.
}

By

Msc. ${ }^{1}$ Eriketa Vladi

\begin{abstract}
Albania has a range of historical, natural and cultural potentials. The marketing strategies prepared with the aim to create and develop Albania's tourism and at what stage is the image of Albania is the subject of this paper. I considered necessary also to conduct a SWOT analysis on tourism development strategies and communication of Albania as a tourist destination.
\end{abstract}

Keywords: Albania, Tourism Communication, Image Management, Destination Branding, Marketing Strategies.

\section{Introduction}

It is impossible to start analysing the image of a country without first mentioning the main concepts established in literature with this regard. For this reason, the first section analyses the latest views in tourism field, some of the marketing tools adopted to promote a country. Destination branding, image management, consumer behaviour, economy of experience and tourist loyalty are some of the concepts stressed throughout this paper.

In order to better understand the strengths, weaknesses, opportunities and threats of tourism development strategies undertaken it is necessary to understand what Albania can actually offer. With this aim, in the second section of this paper, the attracting factors that may transform Albania into an authentic tourism destination are presented. A reference to the main Albania's tourism products is made and an updated overview of tourism current situation is presented.

The third section consists in a SWOT analysis to assess all the strategies elaborated so far to develop tourism in Albania, their efficacy or deficiency. 


\section{Tourism communication: building a country image}

Tourism communication involves selected, coherent and clear information which is offered to a tourist to persuade him choosing one place instead of another (Urry, 1995). This communication should be structured at every step therefore to induce in the tourist mind the conviction he really made the very right choice. This conviction should persist in three stages before, during and after visiting the destination.

In overall terms, the rise of living standards, access to internet, opportunity to read in real time in social media blogs different impressions of people whose intention is not to persuade since they have no interest in expressing a favourable or contrary opinion, allows people to gather many information on countries. They compare this information and ask for an advice to their friends before deciding which country to visit. From a marketing point of view a crucial element not to be forgotten is that as a consequence of the information gathered they establish in their minds a 'specialised visual sense' (Ousby 1990). On the other hand, tour operators also try to understand this individual specialized visual sense and translate it into a simply, believable and close to the reality communication based on tourist market segments. This communication many times fails if it is too similar with the communication of the competition and if it doesn't have the element of distinctiveness. There are many friendly places out there (Morgan et. al. 2012)

Consumer behaviour has been subject of studies to the minimum details. This to enable understanding different needs for each target, why people would buy the product they do and how they make their decision (Horner and Swarbrooke 1996), which is the expected quality and how this quality is perceived (Aaker 2002). It takes a special importance in tourism because before every communication on tourism, tourist behaviour must to be studied. Operators can project how tourist will behave in the future only based on these studies. This in order to meet tourist needs in the best way (I. R. Doole \& Lowe, 2008) or to create new offers that if adequately communicated constitute an added value and in the same time are also another way to generate profits. Tourists decide to choose one country instead of another based on brand awareness. Therefore, the instruments and strategies elaborated for the governance of companies, such as branding, image management measurement of quality, can also apply for the governance of a country brand perception. (Aaker 2007). The American Marketing Association states that a brand is "a name, term, sign, symbol, or design, or a combination of them, intended to identify the goods or services of one seller or group of sellers and to differentiate them from those of competitors"'. If the steps and strategies for building a country brand are faced properly, they lead to a competitive advantage toward other states. The mind of the tourist is 'educated' to filter information and to rate brands. In this world where the globalism has affected every sector with similar information rating becomes a necessity for the tourist and a possibility of a higher positioning for operators involved in tourism. From a survey conducted by top-of-mindbranding a lack of differentiation (44.7\%) and poor communication of brand attributes ( $32.7 \%$ ) were selected as two very important reasons for ineffective branding. ${ }^{2}$

${ }^{1}$ http:/ / www.marketingpower.com/mg-dictionary-view329.php

${ }^{2}$ Report of 2011, in www.topofmindbranding.com 
Let us now turn our attention to the importance that has a brand in defining the image of a country. A necessary step to design tourism development strategies is assessing a country's image and how it compares to its competitors image. The ability of tour operators, private stakeholders, in collaboration with governmental structures, to interact with each other for creating an authentic country brand has not only economic benefits, but at the same time facilitates the process of building the country's image and a better reposition in the consumer's mind (J. Staab M., 2003). Strategic image management is the ongoing process of researching a place's image among its audiences, segmenting and targeting its specific image (Kotler 1993). There are many determinants of a country's image, but an aspect that recently occupies a very important role in building a positive country image is the descriptions of the sites in literature books and filmmaking. It is sufficient for our purpose to mention the movie Letters to Juliet, filmedin Italy, Verona. Casa di Giuglietta, Adige, Soave, Paglio di Siena, Caparzo are only some of the sites filmed and at the same time indirectly promoted, which attracted the attention of many tourist to visit Verona. 'The Da Vinci Code' by Dan Brown, it was a very successful novel first and after was adapted into a movie, is another representative of how movies can become one of the main engines of the communication of a tourism destination. It managed to raise significantly visits to the Louvre's pyramid, Saint-Sulpice church, and other sites filmed in it. Tour operators and travel agencies have created different itineraries for various groups, mainly from the U.S., to visit the places described in the novel or shot in the movie. The payment for these itineraries exceeds 740 dollars, because mystery always appeals to people (Doland A. 2004).

Although many of the organizations that deal with destination branding cannot control production of movies, they can still be more active in finding new ways to promote their territory, and to attract somehow moviemakers to choose this territory instead of another. In order to have an idea on how important it is to promote the image of the state through the induction of the image in the literature and movies it is enough to have a look at the table below:

Tab.1 The impact films have on th visitor number of a Location

\begin{tabular}{|lll|} 
Film & Location & Impact of visitor number \\
\hline Braveheart & Wallace Monuments, Scotland & $300 \%$ increase after a year release \\
\hline Mission Impossible 2 & National Park, Sydney & $200 \%$ increase in 2000 \\
\hline Pride and Prejudice & Lyme Park, England & $150 \%$ increase \\
\hline Troy & Canakkale, Turkey & $73 \%$ increase \\
\hline Harry Potter & Various Locations in England & $\begin{array}{l}\text { All locations saw an increment of } 50 \% \text { or } \\
\text { more }\end{array}$ \\
\hline Notting Hill & Kenwood House, England & $10 \%$ increase in a month \\
\hline
\end{tabular}


35.000 visits in 1991 , steady increase every

Field of Dreams

Lowa year

Four weddings and a The Crown Hotel, Amersham, funeral England

Fully booked for at least three years

Source: Riley and V an Doren (1992): Tooke and Baker (1996) Gribault (2003 Croy and Walker (2003

Cousine and Anderek (1993; Busby and Lund (2003) Riley, Baker and Van Doren 1998.

Attracting tourists, investment companies and reposition are all inseparable chain links of a positive image and which follow subsequently with a significant improvement in all economic disciplines involving tourism.

The relevance of tourism communication, meaning building a country brand and reposition of a country image, has as aim one of the most important concepts of marketing, that of destination loyalty. Although an indisputable response has not been attained by researchers on destination loyalty concept, destinations can be considered as products, and so as the products they can be re-elected. Bignè in 2005 considers that it is difficult to measure loyalty because tourists may prefer to visit new places. In the literature published so far and analysed by Campon A. M., Alves H., and Jernandez J. M., (2013) loyalty appears as a result of models which combined, mainly construct such as satisfaction, quality, image, and value.

Although in this paper I mention some of the main elements that may constitute an effective communication of a touristic destination, the tourist considers his experience in another state as a package. He doesn't analyse separately the different operators involved in the service. What tourist wants and consumes in a destination is a human experience (Magliulo A., 2007), he will remember and will speak about his impressions on the whole journey. That is the reason why along with the purpose to increase the number of tourists should also be considered destination resources (from a protection perspective), their preservation, appraisal, helping tourists to create an unforgettable experience, personal involvement and a warm welcome from residents.

\section{Does Albania have the attractive factors to be considered a touristic destination?}

Albania is perhaps one of the countries throughout the Balkans less chose as a tourist destination. Albania has an imprecise and negative image based on lack of information (Tourism Development International, 2010, pg 1 ). The dictatorship period where Albanians were totally isolated is one of the main elements that has mostly influenced in not establishing a clear and positive image of Albania. But, from a marketing point of view even the communist period that in itself was dark, it marked Albania with an interesting attraction: bunkers. One for every four inhabitants, around 700,000 bunkers were built in the country encouraged by an absurd fear of a possible invasion (NTA). Albanians see these bunkers as an element that reminds them the hard period they had to face during the communism but the younger generation considers this phenomenon interesting and are curios to better understand their past. 
However, this country that confines with Montenegro, Macedonia, Kosovo and Greece and Adriatic and Ionic Sea is recently considered a very interesting destination to visit. Lonely Planet currently has labelled Albania as 'Awaking Sleeping Beauty' we can speak of a start of the tourism phenomenon in Eagle Land ${ }^{3}$ only after 1992. Organization and coordination of tourism in Albania is conducted by the Ministry of Urban Development and Tourism. Departments that depend directly from the Minister and that are responsible for the promotion of tourism in Albania are; General Directorate for Tourism and Cultural Heritage, National Tourism Agency and Tourism Service office.

In order to use a swot analysis to assess the promotion of Albania's image and how did these bodies worked together in developing this country image, we should firs briefly understand what this country actually offers.

Sun \& Beach is one of major tourism product. Albania has a coastline of $450 \mathrm{~km}$ on the Adriatic Sea and Ionian Sea. Some of the more important beaches that we can mention are: in the north Velipoja and Shengjin; in the centre, Lalëzi bay, Durres, Mali I Robit, Spille and Karpen; while in the South beaches of Vlora, Ksamili, Orikumi and Himara etc. ${ }^{4}$

Mountain tourism in Albania is one of the more favourites recently. Albania has seven national parks: Divjaka forest park in Lushnja, Dajti in Tirana, Lura in Diber, Thethi in Shkodra, Llogara in Vlora, Drenovë in Korce, and Hotova in Përmet. I would like to highlight Thethi Park that is located in the Albanian Alps, near the Accursed Highlands (Bjeshket e Namuna), $70 \mathrm{~km}$ from Shkodra, and has an area of about 2,630 hectares. A very interesting natural attracting factor in this part is Grunas waterfall. Its waters descend from a height of 30 meter. Since in Albania tourism peaks are in July and August, one idea of off-season marketing is 'The project of 40 Inns' promoted by Ministry of Tourism Youth and Sports. Inns are small guesthouses, in north Albania with a traditional structure, built in the form of towers, and in the past offered hospitality, accommodation and food for people who encountered themselves in long roads and need a place to stay.

Archaeological tourism also constitutes an attractive factor. Building and monuments belong to Greco-Roman, Ottoman and Byzantine period. There are over 2000 items considered areas and cultural monuments (OECD Tourism Trends and Policies 2012, pg 4). Castle are located in almost all major cities of the country. The second largest Roman Amphitheatre in the Balkans is located in Albania's port city of Durres. Built in the 2nd century AD, the theatre could hold 20,000 spectators (NTA). I will not explain each of the archaeological sites because it is not the purpose of this study but what I want to highlight is the fact that three of these, Gjirokastra "The stone castle", Butrint "The museum city", and Berat "The city of thousand windows", are declared World Heritage Sites and are protected by UNESCO.

In this paper I made a distinction between archaeological and Cultural tourism. There are different views on what is considered a cultural tourism, in this presentation is intended "whatever is distinctive about the 'way of life' people, community, nation or social groups" (Hall, 1997). Albanian culture perhaps is the tourism product less appreciated as

${ }^{3}$ As is this country named by the same Albanians.

${ }_{4}^{4}$ Tourism and Environment in European Countries, Issues 18-83. 
it has not been carried out a proper communication, and often is associated with archaeological tourism. Hospitality, Code of Honour (Besa), Courage, are only some of the aspects that have accompanied the Albanian identity for years and years. At a time when there laws did not exists, or the rule of law was weak in some areas, Albanians obeyed to four codes: The Kanun ${ }^{5}$ of Leke Dukagjini, The Kanun of Skanderbeg, The Mountain Kanun and The Kanun of Laberia. Kanuns were learned by heart and transmitted orally from generation to generation until at $20^{\text {th }}$ century were codified and written down. There is a fascinating history mixed with tradition, mystery and curiosity behind the four Kanuns and how they evolved influencing the culture of Albanians. Another very important element of Albanian culture are also the traditional clothing, dances and folk songs. Folk Festival is the most important festival in the country that in the best way describes this part of heritage. It takes place every four years. The first Folk Festival was organized in 1968 and since then has brought more artists each year performing the different cultural peculiarities of each different area. The Festival attracts over 1,000 artists from Albania, Kosovo, Macedonia, Serbia, Italy, Germany, Switzerland and the United States (NTA). It is organized in different cities of Albania, sometimes in north, sometimes in centre, and sometimes in the south of Albania: this to give the idea of unity between all Albanians. One of the distinctiveness of this cultural event is listening labuta and the iso-poliphony style of Albanian folk singing which has been stated by UNESCO as an "intangible cultural heritage"6

As for gastronomic tourism, Albania is a very rich country with different cuisine that represents a rich historical past. The food of modern Albania has been developed over millennia reflects a variety of influences. Unfortunately, to this topic has not been given a high importance yet. Studies are very few and not structured in this field.

Accommodation structures have evolved. Currently there are around 627 hotels in Albania and 908 (NTA)tourist accommodation unit. Thanks to the Luxembourg funding through the EBRD Business Advisory Services (BAS), Albania in partnership with Albanian Tourism Association and USAID Project "Development of Albania" created the authentic Albania quality mark website. This web site summarizes some of the best and traditional hotels that are reliable and offer tourists the possibility to make online bookings. ${ }^{7}$

Transportation structures allow tourists coming either through air, sea and land and more reconstructions of internal roads facilitate interaction of various operators involved in tourism industry.

Due to the attracting factors presented above, Lonely Planet, in 2011, ranked Albania as the number one recommended destination to visit.

\footnotetext{
${ }^{5}$ Kanun is a set of traditional Albanian law

${ }^{6}$ www.balkansgeotourism.travel

7http://www.authenticalbania.com/hotels-awarded
} 


\section{Strengths, Weakness, Opportunities and Threats analysison the development strategies of tourism in Albania.}

Three strategies were elaborated with the aim to develop tourism in Albania. First strategy was that of 1993 that was planned until 2010. It was written down by a consulting company, which was contracted by European Bank for Reconstruction and Development in collaboration with Albanian Ministry of tourism. This strategy was drafted in a very difficult context because Albania was in early stages of dealing with this field. Although some advice were given about building a marketing strategy in tourism, the only outcome of this first strategy was the approval of the law on tourism that established several priority areas for tourism development.

The second strategy, 2003-2012, was prepared by the Ministry of Territorial Adjustment and Tourism, with assistance provided by the project "Support to the Development of Tourism in Albania", the company contracted was GTZ Ghh Wiesbaden (Tourism Sectorial Strategy 2007 - 2013). Despite that it was a very detailed strategy, where the objectives were established both in short-term and long-term, it remained a theoretical strategy. Operators involved could not implement many of the tasks, such as a detailed analysis of competitors, repositioning the image, the prohibition of abusive buildings established in the strategy. A positive result of this strategy was the creation of the National Agency of Tourism and Albanian Tourism Association.

The third strategy "Tourism Sectoral Strategy 2007 - 2013" is prepared only by the Ministry of Tourism. It is an analysis of two previous documents where objectives are updated and focussed on cultural tourism. A very important and detailed document focused on Albanians culture marketing strategy was prepared in 2010 by Tourism Development International with the support of MDGIF - United Nations. This document refers to the term culture intending a cluster of tourism products whose marketing is subjected to the environmental where experience is consumed (Dietvorst, 1994), so it does not consider the power of diversity that lies in the way of live, practices, symbols. Although Albania counts on a rich culture, there is low consciousness for this tourism product not only of the tourist but also of Albanians themselves. An adequate communication has never been made in this field also because private and public operators involved in tourism industry are not aware of the importance of preserving culture, in all the meanings this concept covers. Because of our difficult past, after the 90' the tendency was to destroy everything that remind communism. Constructions arose uncontrollably and without an urban planning. This damaged directly many culture monuments, likewise private homes are built just next to Amphitheatre of Durres without considering the fact that these homes hide totally the location of this site.

If we take into account the period from 2001 until 2011, we see that over the years there has been an increase of the arrivals and departures of passengers in Albania, but this number does not mean this increase was a result of the strategies undertaken, it is more an uncontrolled growth. The reasons of growth of tourism in Albania were analysed by a survey conducted by Tourism Development International in 2012. There were many products presented as alternative to the question why you visit Albania $40.9 \%$ of the people questioned respond 'other', which means that it was none of those predicted and developed to attract tourists. 
Currently, the Institute of Statistics provides the following information on tourism in Albania:

\section{In bound and outbound tourism in Albania}

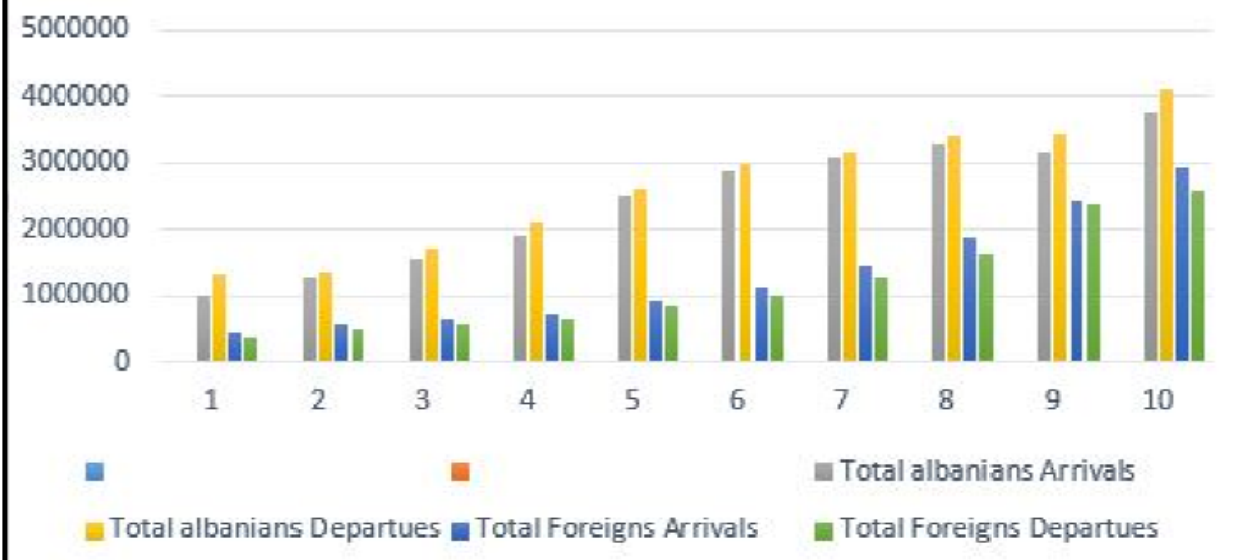

Fig. 2, The growth of tourism from 2001 until 2011, Source INSTAT

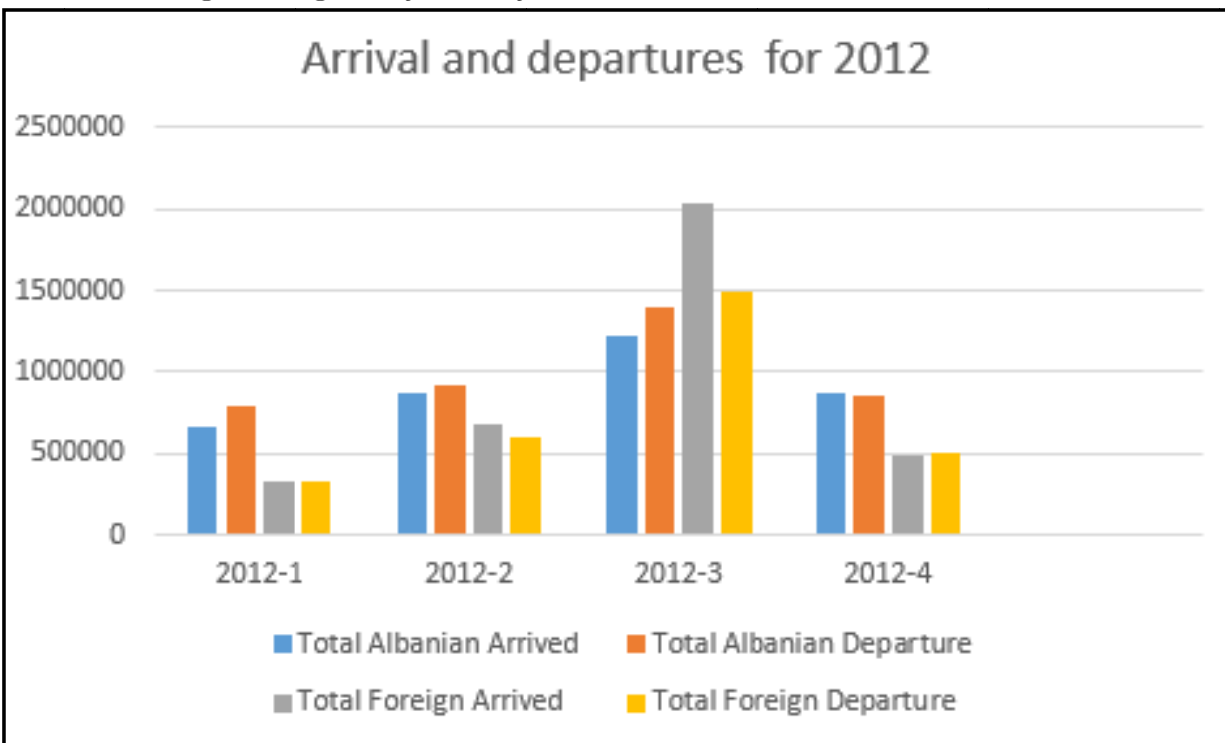

Fig. 3, Arrival and departures for 2012, Source INSTAT 
Below we have the figures of the European Countries with the largest number of visitors to Albania for 2012.

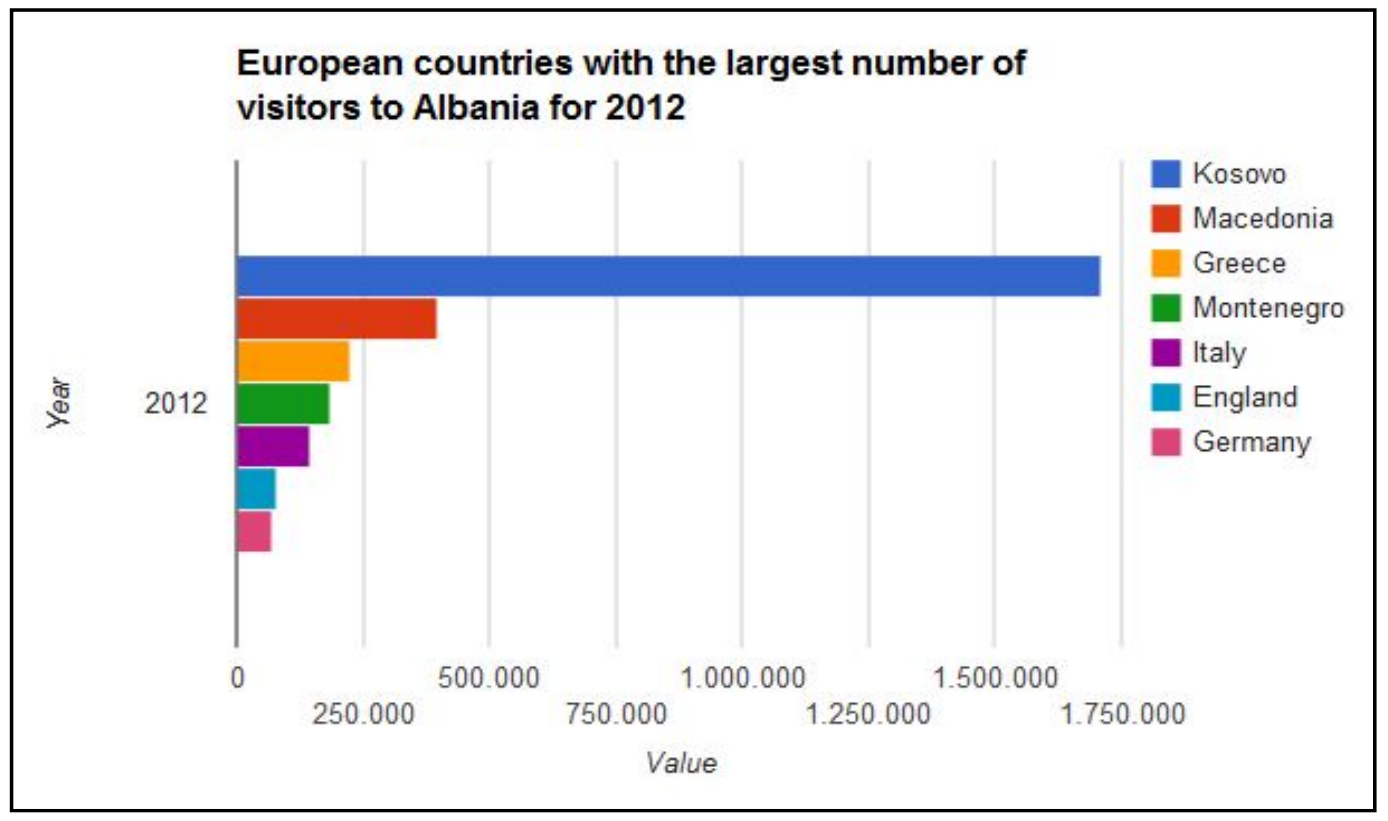

Fig. 4 Source: MTKRS, comments and analyzing Oda.

5. Implementation of a SWOT analysis on Albania's tourism development and communication strategies.

\subsection{Strengths:}

- $\quad$ Albania has a very good geographical position. Tourism sites are close to each other so both mountain area sand sea's beaches can be seen in one day.

- There are some European projects that collaborated with the Ministry of Tourism to establish a proper image of this country, so the first steps are realized with assistance of professional experts.

- $\quad$ Although tourism development strategies did not reached fully their objectives, a point of strength is that anyway in Albania tourism is increasing.

- Albania is mentioned in the literature books like "High Albania" by Edith Durham, Childe Harold's Pilgrimage by George Gordon, Lord Byron. Whoever reads these literatures books it surely becomes curious of knowing "the land of the living past" (Durham E., 1909).

- Albanians personalities known internationally as writers Ismail Kadare and Dritero Agolli, ballerinas Kledi Kadiu, Gert Vaso, singer such as Rita Ora and many others in different countries contribute to promote Albania all over the world as a destination where art counts and it is of a high level. 


\subsection{Weaknesses:}

- The marketing concepts that I address in the first part of this lecture; destination branding, image management and tourist loyalty were not clearly established in the three strategies. The logo to identify Albania as a touristic destination it has changed often (Albania, all your To Be discovered, The land of Eagles and Albania a new Mediterranean love). It gives the impression like even the organizations dealing with promotion of this territory have not very clear in mind what they want to communicate. Changing very often the strategies without fulfilling the objective of the previous one. It fails to create an immediate perception to the tourists and a distinctive element toward other destinations.

- A concrete research on the competitive destinations, both from a territorial positioning perspective and tourism products they offer, it has not been done properly.

- It was not laid down practically how can cooperate all small enterprises operating in the tourism industry to develop sustainable tourism. Sustainable tourism development is mentioned in all three strategies but only in theory. No concrete steps are foreseen such as, meetings, conferences, studies that should enrich this field which at the same time is a sure economic development in long-term and a very important issue for the preservation of the identity of a country.

- Data on tourism are not structured properly. INSTAT provides data on tourism based on police database of arrival and departure of foreign and Albanian citizens but does not consider any other data such as where tourists stay, which is the purpose of their travel, are they really tourists or visitors of this country.

- If one of the strengths is also literature that invites to visit the Land of Eagles, quite different happens with films that mention Albania. Often we find this country associated with mafia (Taken), with revenge (Der Albaner) or other topics that present Albania as a non safe destination. In these moving the shooting scenes do not reflect the natural beauty of Albania, but rather the underdevelopment and poverty.

- Training of human resources on the importance of a quality service is in the first steps. Another point of weaknesses is also the absence of a journal that contains annual studies only for tourism, offering in this way the opportunity to train professionals in this field.

\subsection{Opportunities:}

- Diversity of tourism product gives the opportunity to tour operators to create a diversified tourism package.

- $\quad$ Given that the image is still elusive, if all stakeholders cooperate, they can build a detailed country branding and image management strategy based on Albanian identity.

- There is not yet a mass tourism in Albania. The opportunity is to use this as a strength inviting in this territory the segment of tourist that want to discover new cultures, new sites and unspoiled coast seas. 


\subsection{Threats:}

- Centralization of decision making in governmental power structures often creates a barrier for the cooperation with the private sector.

- Lack of appropriate training on a quality service cannot establish a relation marketing meaning a tourist destination loyalty.

- The recent political change in Albania ${ }^{8}$ may subsequently lead to also a change of the strategies adopted. The threat is that again new strategies will be elaborated but without firstly achieving the objectives set out in the prior strategy.

\section{Conclusions}

There have been three important strategies to develop tourism in Albania but this country still lack an authentic brand as tourism destination. With regard to perception of this country, Albania from an isolated and not safe state, now is considered a fascinating country (Exodus), Europe next adventure destination (Gira L., 2012). As a destination not exploited yet from the mass tourists that visit Albania search an adventure, something new, but this segment is almost never loyal. Strategies should consider to attract also other segments that have more power of expenditure, and that can be subject to destination loyalty strategies, while for the current segment that visit Albania, should be taken into account to develop word-of-mouth or buzz marketing strategies so tourists can be promoters of a positive image of this country.

Tourism continues to increase, thanks to the variety of tourism products present in territory and this is positive anyway, but the fact that this growth is not analyzed properly to understand the reasons behind, and that currently there are many weaknesses and threats led me to consider of a prior importance to establish and implement a strategy involving specially private operators in order to increase awareness of the importance in long term of this collaboration.

The economic crisis all the world is facing today needs alternative and immediate solutions. I consider that for Albania this solution resides in establish a long-term strategy for the development of sustainable tourism, involving all the stakeholders and planning concrete steps to finally achieve a good position as a tourism destination.

\section{References}

Albanian Ministry of Tourism, Culture, Youth and Sports (2007) Tourism Sectorial Strategy 2007 2013.

Albanian Ministry of Tourism, Culture, Youth and Sports, (2005) Strategy and plan of action for the development for cultural and natural tourism.

Argano L., Bollo A., Dalla Sega P., Vivalda C., (2005) Gli Eventi Culturali, FrancoAngeli.

${ }^{8}$ In June the election were wined by Socialist Party. The Democratic had been in power since 2005. 
Bellagamba A., Brunetti F., Pencarelli T., Vigolo V., (2007) La letteratura Italiana ed Internazionale sul Destination Management inGoffi. G (2010) Management delle destinazioni turistiche: sfide per territori e imprese. Il caso di Senigallia e delle Valli Misa e Nevola, FrancoAngeli.

Campon A. M., Alves H., and Jernandez J. M., (2013) Quantitative Methods in Tourism, SpringerVerlag Berlin Heidelberg.pg 13 - 41,

Cassa F., (2008)Analisi Strategica e Marketing per i Mercati Emergenti, LED Edizioni Universitarie.

Doland A. (2004) 'Da Vinci Code' Spawns Travel Fad The Associated Press retrieved from http://www.cbsnews.com

Doole I. \& Lowe R., (2008) International Marketing Strategy, Thomson Learning.

Durham E., High Albania, 1909 retrieved frombttp://wmw.scribd.com/doc/10928654/High-AlbaniaEdith-Durham-1909

Ellul A.,Tourism and Environment in European Countries (1996), Issues 18-83, pg 33 -37.

Fetahu A., Dështimi $i$ strategïve në turizëm (Failure of strategies in tourism) published on Vitrina University Official Web Site.

Hudman Ll. E., Jackson R. H. (2003) Geography of Travel and Tourism, Cengage Learning, pg 294 296.

Hudson S. and Ritchie Brent J. R. Promoting Destinations via film tourism, An empirical identification of supporting Marketing Initiatives, Journal of Travel Research, May 2006 vol. 44 no. 4 387-396

J. Staab M., (2003) Public-Private Sector Relationship in Developing Countries Journal of Economic Development. Vol 28, No 2.

Kadauku I., (2012) The Past, the Present and the Future of the Albanian, TourismJournal of Knowledge. Issue 8.

Law, no. 9734, dated 14.05.2007 “On Tourism”

Leyla Gira (2012) 10 Reasons why 2013 Is The Time To Visit Albania. The Haffington Post.

Leyla Gira (2012) 10 Reasons why 2013 Is The Time To Visit Albania.

Maccarrone Eaglen A. (2009) An analysis of culture as a tourism commodity. Tourism, Culture and Comunication, Vol 9.

Magliulo A., (2007) Elementi di Economia del Turismo, Firenze University Press, chap 1, 2, and 6.

Morgan N., Pritchard A., Pride R. (2012) Destination Branding, Routledge.

Murphy S. A., El-Banna A., Rojas-Méndez J., Papadopoulos N., (2009) Examining the validity of the country brand personality Construct,Sprott School of Business, Carleton University.

OECD Tourism Trends and Policies (2012), Pg 324 - 328

Park S.Y., Ewha W., Mi Lee E., Congruence between brand personality and self-image, and the mediating roles of satisfaction and consumer-brand relationship on brand loyalty.. in AP - Asia Pacific Advances in Consumer Research Volume 6, eds. Yong-Uon Ha and Youjae Yi, Duluth, MN : Association for Consumer Research, Pages: 39-45.

Report Challenges and Opportunities in Effective Branding, 2011, retrieved in www.topofmindbranding.com

Sustainable Tourism Development: Proceedings (9-11 November 1995, Cyprus). Colloquy Organised by the Council of Europe (Directorate of Environment and Local Authorities), the Cypriot Ministry of Agriculture, Natural Resources and Environment and the Office of Tourism of Cyprus, Larnaca, Pg 117 -118.

Swarbrooke J., Horner S. (2007) Consumer Behaviour in Tourism Routledge-, chap 1, 2, 3.

United Nations, Economic Commission for Europe, Albania Environmental Performance Review 2012 as retrieved from http://www.unece.org/fileadmin/DAM/env/epr/epr studies/Leaflet/Booklet EPR Albania.pdf

Urry J. (1995) Consuming Places, Routledge, pg 129 - 173. 